Daniela Marčoková*

UDC 811.162.3’373.2(497.113 Kisač)

Anna Makišová

DOI: $10.19090 / \mathrm{gff} .2017 .1 .291-303$

Filozofická fakulta

Стручни научни рад

Univerzita v Novom Sade

\title{
PRÍMENÁ V KYSÁČI AKO KULTÚRNE A TRADIČNÉ DEDIČSTVO**
}

Predmetom výskumu bola neúradná pomenovacia sústava obyvatel'ov Kysáča, ktorí sú slovenskej národnosti. Ciel'om výskumu bolo evidovat' prímená dospelých obyvatel'ov Kysáča, ktoré sa vyskytovali v druhej polovici 20. storočia, na prelome tisícročí a tie, ktoré sa dodnes používajú v každodennej komunikácii. Vo výskume sme uplatnili metódu živej pamäte. Výsledky nášho výskumu môžeme zhrnút' takto: pri 165 priezviskách sme zaznamenali úhrnne 742 prímen; niektoré rozvetvené rodiny majú vel'a prímen. Hoci sú jednočlenné modely najčastejšie, zaznamenali sme i dvojčlenné opisné modely; niekedy má jedna osoba dve prímená; niektoré prímená sa vzt’ahujú na niekol'ko osôb; prímená najčastejšie majú pozitívny postoj k osobe, no je aj určitý počet takých, ktoré vznikli podla animozity. Prímená považujeme za súčast' kultúrneho a tradičného dedičstva.

Klúčové slová: onomastika, prímená, Kysáč, Slováci v Srbsku, kultúrne a tradičné dedičstvo

Kysáč je slovenská osada vo Vojvodine (Srbsko), do ktorej sa prví Slováci prist'ahovali roku 1773. Podl'a posledného súpisu roku 2011, v Kysáči žilo 5670 obyvatel'ov. V súčasnosti je t’ažko určit' presný počet obyvatel'ov Kysáča slovenskej národnosti kvôli novodobým migráciám, no predpokladáme, že dnes v Kysáči žije približne 4000 Slovákov. Ked’že registrujeme zmenšenie počtu obyvatel'ov slovenskej národnostnej menšiny na týchto priestoroch, považujeme, že naša práca bude prínosná v zmysle zachovania svedectva na časy, ked' tu žili Slováci vo väčšom počte.

Ciel’om našej práce bolo zaznamenat' prímená ako súčasných a žijúcich obyvatel'ov Kysáča, tak i osobné a rodinné prímená, ktorých nositelia už nežijú v Kysáči, alebo už nežijú vôbec, alebo i také prímená, vzt’ahujúce sa na priezviská, ktoré v Kysáči zanikli.

Vo výskume sme uplatnili metódu živej pamäte (podobné termíny sú kolektívna a komunikatívna pamät'), ktorá je výhodná najmä pri skúmaní

\footnotetext{
*danielamarcokova@ff.uns.ac.

** Príspevok vznikol v rámci projektu č. 178017 Diskurzy menšinových jazykov, literatúr a kultúr v juhovýchodnej a strednej Európe, ktorý financuje Ministerstvo školstva a vedy Srbska.
} 
vnútorného poznania určitej sociálnej skupiny. Živá pamät’ je fungujúca výlučne na sociálnej úrovni pri komunikácii, ktorá sa uskutočňuje v každodenných situáciách. Trvá približne sedemdesiat až osemdesiat rokov alebo približne tri za sebou nasledujúce generácie, pričom sa objem zapamätaných informácií časom znižuje.

Kvôli zachyteniu čím širšieho časového úseku s dosahom na čím d’alšiu minulost', informátormi boli príslušníci staršej a strednej generácie obyvatel'ov Kysáča ${ }^{1}$. Materiál sme získavali vlastným terénnym výskumom v rokoch 2016 a 2017, zámerne volenými návštevami osôb, pre ktoré sme predpokladali, že poznajú väčšinu obyvatel'stva.

Bez ohl'adu na to, že sme $\mathrm{v}$ práci nedávali do súvisu priezviská $\mathrm{s}$ prímenami, pri zaznamenávaní prímen sme vylúčili tie, pre ktoré sme zistili, že sú urážlivé pre osobu alebo rodinu. Ospravedlňujeme sa $\mathrm{v}$ prípade, že nám predsa „unikli" niektoré prímená, ktoré niekto bude považovat' za nelichotivé.

\section{VÝSKUM V OBLASTI ONOMASTIKY V RÁMCI SLOVENSKÉHO VOJVODINSKÉHO PROSTREDIA}

Daniel Dudok ${ }^{2}$ dôkladne preskúmal pôvod a význam priezvisk Slovákov vo Vojvodine. Transkripciou priezvisk do slovenčiny a srbčiny a opačne sa venovali zamestnanci Oddelenia slovakistiky ${ }^{3}$. Jazykovou kultúrou mena, menom a národnou identitou sa zaoberali: Michal Týr, ${ }^{4}$ Anna Marićová, ${ }^{5}$ Anna Makišová ${ }^{6}$ a Zuzana

${ }^{1}$ Informátori: Michal Ďurovka - Profesor (1946), Mária Ďurovková (rod. Németová) Nímetka (1949), Ján Ďurovka - Dubček (1939), Ondrej Ďurovka (1939), Michal Filko Šešelj (1941), Michal Gombár - Učitel' (1933), Ondrej Hriva - Kŕmo (1948), Anna Madacká (rod. Ivičiaková) - Tuškovka (1957), Ján Madacký (1951), Anna Surová (rod. Ďurovková) Surovka (1944) a Anna Legíňová (rod. Páliková) - Rafova (1946).

${ }^{2}$ Dudok, D. (2001). Priezviská Slovákov v Juhoslávii. Nový Sad: Spolok vojvodinských slovakistov. Dudok, D. (2006). Pôvod Hložančanov z hladiska ich priezvisk. In: Hložany 1756-2006. Zborník prác pri príležitosti 250. výročia príchodu Slovákov do Hložian. Hložany: MOMS; Báčsky Petrovec: Kultúra. 261-271.

${ }^{3}$ Marićová, A. \& Týr, M. \& Makišová, A. \& Týrová, Z. (2011). Transkripcia priezvisk zo slovenčiny do srbčiny. Nový Sad: Národnostná rada slovenskej národnostnej menšiny.

${ }^{4}$ Týr, M. (2004). Meno a národná identita. Slovenčina v praxi. Štúdie z konfrontačnej a aplikovanej lingvistiky. Nový Sad: Futura publikacije. 38-45.

${ }^{5}$ Marićová, A. (2015): Priezviská ako živé mená staropazovských Slovákov. In: 19. Slovenská onomastická konferencia. Bratislava: Veda, vydavatel'stvo Slovenskej akadémie vied. 118-127; Marićová, A. (2015). Neúradné priezvisko vo funkcii živého mena u staropazovských Slovákov. In: Diskursi manjinskih jezika, književnosti i kultura u 
Týrová. ${ }^{7}$ Problematike priezvisk sa sčasti venoval i Miroslav Dudok. ${ }^{8}$ Okrem toho, Samuel Čelovský sa v súčasnosti zaoberá skúmaním priezvisk v Kysáči (práca ešte nie je publikovaná). Prímená (prezývky) v Pivnici skúmali Zuzana Týrováa a Ján Botík. ${ }^{10}$ Ján Kováč knižne spracoval problematiku dvojakých priezvisk v Starej Pazove $^{11} \mathrm{v}$ rámci ktorej okrajovo uvádza prímená a prezývky. Podl'a nášho zistenia, v minulosti boli pokusy o zaznamenávanie prímen miestnymi obyvatel’mi Kysáča, no okrem rukopisu Michala Párnického, v ktorom zaznamenal približne 120 prímen (pravdepodobne v 70. rokoch 20. storočia), iné zoznamy sa nezachovali.

\section{DEJINY POUŽÍIVANIA MIEN}

Dávanie mena a priezviska novorodencovi je regulované zákonom. V úradnom styku sa u Slovákov uplatňuje dvojmenná sústava osobných mien, pozostávajúca z osobného mena (krstné, rodné meno) a priezviska (dedičné rodinné meno).

V období pohanstva predkovia Slovákov dávali svojim det’om slovanské mená, kým po prijatí krest’anstva to boli krest’anské starozákonné a novozákonné mená. Jednomenná pomenovacia sústava bola príznačná ešte i pre stredovek. Podl’a Kršku (2003: 213) naši predkovia sa prijatím krest’anstva neradi vzdávali tradície slovanských mien a tak jedno meno (väčšinou krest’anské) dostal človek pri krste,

jugoistočnoj i srednjoj Evropi. Ministarstvo za nauku i tehnološki razvoj Republike Srbije. 79-86.

${ }^{6}$ Makišová, A. (2015). Miestne názvy a obyvatel'ské mená vo Vojvodine. In: 19. slovenská onomastická konferencia. Bratislava: Veda, vydavatel'stvo Slovenskej akadémie vied. 206213; Makišová, A. (2015). Slovenské priezviská vo vojvodinskom kontexte. In: Jazykovedné štúdie. 32: prirodzený vývin jazyka a jazykové kontakty. Bratislava: Slovenská akadémia vied; Makišová, A. (2014). Zapisovanie slovenských priezvisk v slovenskom a v srbskom kontexte. In: Godišnjak Filozofskog fakulteta, Novi Sad. roč.39, č.2. 93-106.

${ }^{7}$ Týrová, Z. (2015). Rodné mená vojvodinských Slovákov (na príklade Pivnice). In: 19. Slovenská onomastická konferencia. Bratislava: Veda, vydavatel'stvo Slovenskej akadémie vied. 138-143.

${ }^{8}$ Dudok, M. (2015). Z chorvátskej a srbskej propriálnej lexiky na Slovensku. In: 19. Slovenská onomastická konferencia. Bratislava: Veda, vydavatel'stvo Slovenskej akadémie vied. 72-77.

9 Týrová, Z. (2005). Prezývky Slovákov v obci Pivnica (Juhoslávia). In: Varia XII . Bratislava: Slovenská jazykovedná spoločnost' pri SAV. 175-179.

${ }^{10}$ Botík, J. (2011): Z historickej a kultúrnej pamäti Pivničanov. In: Dolnozemskí Slováci. Nadlak: Vydavatel'stvo Ivan Krasko. 139-141

${ }^{11}$ Kováč, J. (2002). Priezviská Slovákov v Starej Pazove. Stará Pazova: vlastným nákladom. 
druhé meno (pohanské) plnilo funkciu prímena (t. j. bližšie charakterizovalo a identifikovalo jedinca): Pauli dicti Koza, Stephano dicto Kurchma, Nicolaus dictus Pohar. Čo sa týka súčasného inventára rodných mien u vojvodinských Slovákov evanjelického vierovyznania, podla Týrovej (2005: 139) bol donedávna relatívne chudobný, lebo sa det'om zvyčajne dávali asi desat' tradičných mien s malými odchýlkami. V súčasnosti zanikajú staré slovanské mená, lebo rodičia detom dávajú jedinečné a moderné mená.

Priezvisko je čast' osobného mena. Je to rodinné (rodové) meno, ktoré sa pridáva k rodnému menu na bližšie označenie osoby. $\mathrm{V}$ rodine sa spravidla dedí po otcovi. Predchodcami priezvisk boli prímená. Dudok konštatuje, že priezvisk je ovel'a viac ako krstných mien (1998).

Prímená začali vznikat' v 10. storočí v západnej Európe. Prvé prímená (prídomok, predikát), mali okrem mena najprv iba šlachtici (red. Kiliánová, 2011). Podl'a Dudka u šlachticov vznikajú prímená v 15. a 16. storočí, kým u mešt’anov a u poddanných na dedinách v 16. a 17. storočí (1998). Podl'a Švecovej sa prímená tvorili rozličnými príponami (napr. Matejov syn Jakub - Jakub Mateje), no v 15. až 17. storočí sa začali pridávat' mená podl'a funkcie, povolania, remesla, majetku, bydliska... Ak sa dedili po otcovi, označujeme ich ako patronymiká, ak po matke, tak matronymiká. Prímeno zvyčajne vytváral zhotovovatel' písomnej listiny, v ktorej použil živú prezývku rodiny. Neskôr sa z týchto prímen vyvinuli dnešné priezviská a definitívnu podobu nadobudla dvojmenná sústava v novoveku, ktorú r. 1780 uzákonil Jozef II a ktorou bolo povinné používat' priezvisko vyvinuté z prímenia (Švecová, 1971). V tomto období už Slováci prichádzali na územie dnešnej Vojvodiny a $\mathrm{v}$ evidenciách dolnozemských cirkevných zborov už nachádzame dvojmennú pomenovaciu sústavu dost’ahovalcov. Podla Dudka tým nezanikla bohatá a rozvetvená sústava živých (neúradných) osobných mien, ktoré slúžia na identifikovanie osoby, presné označenie $\mathrm{v}$ dedine, susedstve, $\mathrm{u}$ príbuzných, v rodine. Kým úradné mená dáva rodina, živé mená a predovšetkým prieliehavé prímená vymýšl’a a dáva okolie. Hoci sú živé osobné mená neúradné, často sú používanejšie od úradných. Používanie prímen v minulosti malo svoje opodstatnenie tam, kde žilo mnoho l’udí pohromade, predovšetkým v mestách. Dnes sa na presnú a rýchlu identifikáciu určitej osoby použivajú živé osobné mená, zvlášt' v dedinských prostrediach (1998: 14).

\section{TERMINOLOGICKÉ VYMEDZENIE TERMÍNOV PREZÝVKA A PRÍMENO}

Základný lexikálny význam slova prezývka vysvetl’uje Slovník slovenského jazyka 3 (1963: 529) ako „trvalé, obyč. posmešné pomenovanie, meno niekoho, 
dané podla charakteristických povahových vlastností, používané popri bežnom mene“. Podl’a Krátkeho slovníka slovenského jazyka (1989: 576) prezývka je „vedlajšie pomenovanie niekoho podl'a charakteristických vlastností", čo si vysvetl'ujeme prítomnost'ou určitej miery expresivity, s príklonom $\mathrm{k}$ pozitívnej alebo negatívnej emocionalite.

Aj podl'a Profantovej prezývka obsahuje prvok hodnotenia, obvykle negatívneho. Práve preto, že je posmešná a blízka nadávke, prezývka býva predmetom hnevu, hádok a iných nepríjemností (ed. Kiliánová, 2011).

Podl’a Murina prezývka v sebe zväčša kóduje príbeh, ktorý pozná väčšina členov komunity. Tento príbeh zväčša sprevádza člena spoločenstva po celý život a pamät' príbehu pomáha identifikovat' osobu v lokalite. Poukazuje na to, že často dochádza $\mathrm{k}$ variovaniu príbehu, ktorý si komunita vytvára a traduje medzi generáciami (2015). Z tohto uzavierame, že je prezývka podl’a neho typická pre malé sociálne skupiny. To môže byt' dedinské obyvatel'stvo, ale aj iné vekovo, záujmovo, profesijne alebo inak sociálne ohraničené kolektívy. Podla Valentovej (2011) v českej lingvistike a onomastike sa termín prezývka používa predovšetkým na označenie neúradných mien žiakov $\mathrm{v}$ školskom kolektíve. Bauko pod prezývkami rozumie „neúradné osobné mená, ktoré si l’udia dávajú v určitej societe, a identifikujú človeka okrem priezviska, krstného mena a hypokoristika“ (2010: 331). Za prezývku pokladá neúradnú formu priezviska a jeho nepravidelnú zmenu a dokonca za prezývku pokladá živé meno, ktoré má iný tvar ako úradné meno.

Prímeno je podl'a Krátkeho slovníka slovenského jazyka (1989: 352) d’alšie meno pridané k priezvisku. Podl'a Valentovej (2010) je termín prímeno zaužívaný skôr pre historické sekundárne mená $\mathrm{v}$ jednomennej pomenovacej sústave pred úradnou kodifikáciou dvojmenného pomenovania. Podla Marićovej „Prímenom sa dopĺn̆a priezvisko na základe určitej individuálnej alebo inej charakteristiky $\mathrm{v}$ spoločenstve, v ktorom je viacej rodín s rovnakým priezviskom tak úradným, ako aj neúradným...". Pripúšt’a i tzv. opisné prímená „,napr. Jano švagríkou, čo má Gašparku (podl'a rodinného priezviska manželky)... Marti Ugoróu s Kurta šoru (podl’a názvu ulice), Vincúrovci čo maju malie oči (podl'a osobnej charakteristiky)" (2015: 120).

Podl'a Profantovej l'udová terminológia často nerozlišovala prezývku od prímena, takže sa paralelne javia termíny ako „prezývané meno“, „prídavné meno“, „prímenie“ (ed. Kiliánová, 2011). S týmto názorom sa stotožňuje aj Dudok, ktorý považuje, že je z dnešnej perspektívy t’ažko rozlíšit' prezývku a prímeno (1998). Prikláňame sa $\mathrm{k}$ tejto konštatácii. Ked’že škála definovania pojmov prezývka a prímeno je príliš široká a niekedy je t’ažko určit rozdiel medzi nimi, v našej práci budeme používat' termín prímeno. Považujeme, že tento termín podl'a svojej 
definície zachytáva širšiu škálu živých mien, ktoré plnia funkciu druhého mena, slúžiaceho na dištinkciu osôb istého mena a/alebo priezviska alebo na presnú a výstižnú identifikáciu osoby v skúmanom dedinskom kolektíve.

\section{DATABÁZA ZAZNAMENANÝCH PRÍMEN V KYSÁČI}

Z registra priezvisk $\mathrm{v}$ knihe Daniela Dudka Priezviská Slovákov v Juhoslávii možno zistit', že zo 4200 spracovaných priezvisk, v Kysáči sú zaznamenané 662 priezviská. Zistili sme, že je 165 priezvisk (čo je približne asi štvrtina z úhrnného počtu slovenských priezvisk v Kysáči), pri ktorých sa vyskytujú prímená. $\mathrm{V}$ našej práci sme nedávali do súvisu priezviská $\mathrm{s}$ prímenami $\mathrm{z}$ objektívnych príčin, takže tu ani neuvádzame zoznam spomínaných priezvisk. Prímená sme zaradili do týchto, na tento účel (,ad hoc") utvorených kategórií: ${ }^{12}$

1. Podl'a mena:

a) podl’a rodinného mena (patronymiká): Bad’inoụci, Ďuróụci, Gájko, Gaži, Geci, Gịera Jerkoví, Jozefóuci, Kacera, Kesjovskí, Kvárik, Lacoví, Lucinskí, Maroụdi, Medl'a, Michl'a, Mitre, Marfécki, Pajkoš, Percel', Pinco, Šafár, Šaụka, Šeki, Štirịiakoụci, Tomášoví, Tuško, Tuška, Žárkoví.

b) podla ženskej línie (matronymiká): Baglášs, Benka, Čjernamara, Domonkin, Ferko, Gerž, Král'oụskí, Makam, Macko, Majtám, Olách, Škurám, Zel'enák.

c) vyvodené z vlastného mena: Ďóko, El’eňim, Ferdinand, Ferejcoví, Gregor, Gusti, Jayco, Jayči, Jaňík, Jojo, Jóškoụci, Jozefóụ, Kájim, Kubo, Lád’o, Mifo, Mišina, Mišík, Miški, Pafo, Pajšo, Paụko, Páụko, Pali, Palo, Petra, Péteroụ, Petroví, Rále, Rášo, Sájo, Sami, Toyko, Tomášoụ.

d) vyvodené z priezviska: Bágo, Baki, Biki, Carko, Céko, Cíne, Crvko, Čéko, Daňiš, Drịenko, Drni, Drínki, Demro, Dubec, Fil'o, Frnt'ík, Fúnto, Gal’o, Gále, Hevír, Saki, Skále, Gédo Grnko, Kíjo, Kíso, Koki, Kóco, Krajlo, Kul’o, Lenko, Máde, Maki, Méco, Médo, Meško, Morvaj, Moško, Muvi, Nasko, Nemeš, Péjo, Pet’o, Pojki, Sádo, Skále, Surko, Širka, Tótik, Vránac, Vrbača, Vŕle, Vlaki, Záborac, Zloch.

e) podl'a srbského mena/priezviska: And’élko, Bájit', Báne, Jovička, Lázo, Miki, Míko, Míto, Móme, Nenad, Nídžo, Pájo, Péko, Radojeụ, Rájko Skoblár, Šimovit', Šinkovic, Tómo, Žíko.

\footnotetext{
${ }^{12}$ Pri uvádzaní prímen sme použili fonetickú transkripciu kvôli tomu, aby sa mohli správne prečítat'.
} 
f) podla cudzieho mena: Čarli (angl.), Dendi (angl.), Díner (Diener židovská rodina v Kysáči), Džini (angl.), Fredi (angl.), Hari (angl.), Henri (angl.), Jusufi (Jusuf - arabská verzia Jozefa), Laci (mad'.), Lari (angl.), Lojzi (mad’arské hypokoristikum Alojza), Paul (nem.), Pišta (mad’arská verzia Štefana) Pedro (špan.), Rajter (nem.), Šándor (mad’.).

2. Podl'a geografického názvu, národného príslušenstva a priestorového rozmiestnenia: Afrikánac, Amerikám, Bád’onskí, Begejáš, Beškam, Bólovčam, Britik, Bugar, Dolinaj, Francús, Horňịak, Japám, Járašoụci, Kinés, Lošíncoụ, Lošinskí, Lužam/Ludžan, Madžar, Nachiški, Nakaydrme, Palášik, Petroụskí, Pilišam, Pirošam, Rus, Sálašam, Sarajevo, Slovák, Solịanski, Srbijánac, Tisoụskí, Told'am, Zabara, Žit.

3. Zvieracieho pôvodu: Cápo, Čenger, Džúkac, Húskár, Insekt, Kacúr, Kanarínac, Kanár, Kóbac, Lapka, Mačica, Motíl', Mucha, Pače, Paprček, Pévac, Pile, Sova, Zajko, Žguňec.

4. Rodinného pôvodu: Apíčko, Apko, Bábo, Báto, Bát’atómo, Bát'oụka, Čikica, Kmotor, Kómšo, Kúmko, Pajtáš, Sakibáči, Sínko, Stríko, Sváko, Svat, Šogi, Švagrík.

5. Podla názvov jedál a nápojov: Brezák, Buchta, Kapusňík, Kašasti, Kuglof, Mlịečkoprevarenụo, Piụkár, Piụko, Rakijáš, Smoki, Špricer, Viski, Zlatorog.

6. Cudzieho pôvodu: Badi, Bekón, Bój, Dobardám, Grín, Gudbáj, Házi, Ime, Kandi, Kiči, Luksus, Momak, Paul, Pionír, Pufi, Stil, Točkár.

7. Podl'a funkcie, zamestania a vykonávania činnosti, názvu podniku: AS, Alcmetál, Alvár, Bábkár, Bačkoráš, Bačoụci, Baykár, Basista, Belzinkár, Bolničár, Bravčjar, Bubnáš, Bundáš, Cenzár, Čelár, Čižmár, Črepár, Darál’oš, Direktor, Díler, Debnár, Doktor, Drevár, Džandár, El'etričịar, Fabrikant, Farár, Farbịar, Financ, Furmičkár, Generál, Geregár, Halogén, Haydrár, Hasič, Hodinár, Hodinkár, Holupkár, Hol’ịar, Hrobár, Hud’ec, Hvezdár, Ihlár, Kalapoš, Kamenár, Kaydrmáš, Kantor, Kapcoš, Kapitán, Kaplánoví, Kinár, Klas, Klkár, Klobučňík, Kloyfer, Kochňịar, Komandír, Kondáš, Korpár, Kováč, Krčmár, Krojáč, Krosnár, L’et'ec, Lovec, Ložáč, L'íškár, Magacíner, Majster, Malịar, Matičár, Medár, Meškár, Metlár, Mesịar, Ml’ekár, Ml'inár, Murár, Muzikant, Novinár, Obuvňík, Ol’ejkár, Organcijáš, Parketár, Paprikár, Pekár, Peváč, Počtár, Podnotár, Pokladňík, Pol’icaj, Pál'eňičịar, Prezident, Profesor, Rol'ník, Rapšicer, Remenár, Repár, Ribár, RTS, Sekretár, Sel’ektor, Sódár, Skel'ịar, Starejší, Stolár, Stražár, Stromíkár, Stuňịar, Šerif, Školňík, Šnajder, Špijúm, Štrangár, Štriker, Štverňịar, Tamburáš, Tamburkáš, Tapetár, Tel'efonista, Tišler, Tkáč, Tortár, Tokár, Trafikant, Traktorista, Trgovcoví, Tréner, 
Truhlị̣ar, Ťehlár, Ťehl'ičkár, Učitel', Umel'ec, Účo, Veterinár, Vulkanizér, Zel'eňinár, Zel'ezňičịar, Zvonár.

8. Podl'a predmetov, rastlín a javov: Cigaráš, Čaura, Čikl’er, Dinár, Dolňíkmakoví, Ikona, Kolibadotrhaná, Papečok, Šarkam, Vaham, Vulkám, Trčika, Tíro, Púderka.

9. Podl'a psycho-fyzických vlastností a stavov: Andačkandač, Bel'o, Bezoka, Bélac, Bịela, Brčkár, Bŕko, Bucham, Cigarkár, Čárni, Čịerni, Čipkár, Daráloš, Dasko, Dáso, Dlhí, Dovec, Drdák, Drdi, Dugi, Ďud’ud'úrko, Frajerkáš, Gŕbo, Gubica, Gušám, Hráme, Hrubí, Janomal'í, Janovelkí, Kido, Konaj, Koškár, Krest’am, Léšo, Lucprdo, Maskota, Mimimíško, Miškagorimlina, Mrmloš, Mocní, Nazarém, Ňemí, Otrava, Papučịar, Perikám, Pirirájko, Pogam, Pravotár, Prl’o, Próbáš, Puyktičkár, Raga, Riško, Smŕdo, Sobotár, Sakramentija, Snágo, Strúja, Šapti, Šišo, Škrípam, Špíco, Tivola, Verní, Volovina, Vihipkár, Zlót'o, Židrák, Žvále.

10. Podl'a kreslených a literárnych hrdinov, známych osobností a udalostí: Alf, Bádžo, Beara, Burduš, Čaják, Dáča, Dejánovit', Dupček, Džonson, Gajger, Hlinka, Jánošík, Kenedi Kít’o, Lumumba, Molotov, Pánto, Paroma, Pinki, Popaj, Ringo, Sayčo, Saydokám, Sịedmikongres, Šešel', Špíro, Tarzam, Titko, Truman, Zoro.

11. Nezaradené: Aňịel’ik, Bačoụka, Bayd’o, Bapsko, Bájko, Beták, Bobek, Boboš, Bohiňa, Boho, Bojla, Bojtár, Bokšam, Bóne, Boroyčák, Boroňjak, Boso, Brčkár, Búko, Búrik, Burkuš, Búšo, Cáco, Cóni, Cicko, Cíco, Cilo, Cípo, Cvetko, Čéčo, Čitrák, Čitrík, Čitro, Dajč, Depóš, Didzgem, Dimi, Dit’o, Díme, Drlo, Drndy, Druso, Dudovec, Dujko, Dupi, Ďájo, Ďetro, Ďico, Dzígo, Džompara, Džúbro, Edo, Fáne, Fero, Fiki, Fír, Flinntaj, Fúso, Garinča, Gazda, Gazd’ik, Gájko, Gedra, Gel’a, Géne, Gráfik, Guča, Gujda, Háňik, Hampora, Hat’apúš, Hekl’a, Hernák, Hergo, Hevír, Heydri, Hoyzo, Horeháj, Hrkúl', Húber, Hurtul'a, Icík, Ido, Ikera, Jávo, Jéụd’o, Jézo, Joti, Juj, Júco, Júso, Kaka, Kalajga, Karči, Kardasko, Kiko, Kil’eycoš, Kolter, Kóle, Kóko, Kotétko, Kŕko, Kŕmo, Kunda, Kurl'ička Kut'ka, Lagúš, Lambi, Laňo, L'ebam, L'egánus/Leghánus, Lemi, Levi, Lina, Lojzi, Lokaj, Lúšt'ik, Lut'ík, L'endi, L'ico, Maco, Mákso, Maroš, Medla, Mécho, Mendi, Mico, Migi, Mígo, Michl’a, Mňačár, Mrnda, Mikac, Mikuš, Mijči, Minder, Míster, Moni, Moňašár, Mŕco, Mujki, Mújit', Ňóko, Ol’o, Oňiš, Paco, Pečjak, Pélo, Pepi, Pili, Piola, Pípo, Pimega, Pindžo, Pirči, Pízo, Prčkalica, Prčina, Raf, Rafka, Rakajlo, Ríto, Rot'ko, Síto, Saks, Sálašam, Sal'era, Sal'ich, Sikvis, Síjo, Símo, Slat'inár, Striška, Suha, Šajo, Šarajda, Šárga, Šimbus, Šindil’ko, Šipci, Šíro, Šíco, Šíšo, Šita, Šmáco, Šmrdam, Šoha, Šok, Šolája, Šprňo, Šticko, Šúco, Šújo, Šúmo, Šuško,Taụdžo, 
Techno, Tind'ír, Tinto, Trajko, Tŕto, Trifke, Ťópo, Ťopso, Ťuňo, Ťúko, Vacho, Vicek, Voki, Vukas, Zél’o, Zúle, Zuštiak, Žajír, Žubal'a, Žúbro, Žújo, Župúl'ko.

Osobitnú kategóriu tvoria ženské prímená. Ženy v Kysáči sú zvyčajne bez prímen. Ak nejaké majú, tak sú vyvodené z manželovho (A¡kapróbna, Bryka, Cácka, Dit'ka, Gedroụka, Grínka, Mécovka), alebo otcovho prímena (Jánošíčka, Jovicóvka). Málo je takých, ktoré majú osobné prímeno (And’ela, Ajkapekná, Kukica, Kata (vlastným menom Alena), Maračierna). Niektoré majú prímeno podl'a názvu zvierat (Čita, Gól’a, Hrlka (hrdlička), Koza, Mače, Riba, Sova, Zebra,); predmetu (Kefa, Sito, Piksl'a); rodnej dediny/miesta pôvodu (Aradácka, Padiłka); zamestnania manžela (Doktorova, Obuvňíkova, Taksistova); podla fyzickej/duševnej vady (Ňemá, Chibná, Pejcejova t.j. Percel'ova, Bezvlasov); podl'a „dievockého” priezviska (Piksika, Srna, Sura, Migal'ica); podl'a známych osobností (Lovisna, Néda Ukraden, Regica, Zlatovláska); iné: Dúša, Džídžoụka, Hucka, Krcko, Srce.

\section{VÝSLEDKY VÝSKUMU}

1. Pri 165 priezviskách sme zaznamenali úhrnne 742 prímen súčasných a žijúcich obyvatel'ov Kysáča, ale i také osobné a rodinné prímená, ktorých nositelia už nežijú v Kysáči, alebo už nežijú vôbec, alebo priezvisko, na ktoré nadväzuje prímeno, v Kysáči zaniklo.

2. Prímená sme roztriedili do nasledujúcich kategórií: podla mena (s piatimi podkategóriami, úhrnne 167); podl'a funkcie, zamestania a vykonávania činnosti, názvu podniku (139); podl'a psycho-fyzických vlastností a stavov (69); podl'a geografického názvu (34); podl'a kreslených a literárnych hrdinov, známych osobností a udalostí (30); zvieracieho pôvodu (20); rodinného pôvodu (18); cudzieho pôvodu (17); podl'a predmetov, rastlín a javov (14); podl'a názvov jedál a nápojov (13). Bolo dost' takých prímen, ktoré boli nešpecifikované, nedefinované a tak sme ich nevedeli zaradit' do spomínaných kategórií (221).

3. Niektoré rozvetvené rodiny majú vel'a prímen (Chrt’an - 37, Marčok 34, Madacký - 33, Durovka - 32, Filko - 27) a v tomto zmysle je ich ovel'a viac ako priezvisk.

4. Niekedy má jedna osoba dve prímená, napríklad jedno prímeno sa vzt'ahuje na zamestnanie a druhé je osobné prímeno (Hrobár/Cóni, Fotograf/Mél'o, Tréner/Morvaj, Ďóko/Obuvník, Ďóko/Grading, Berzo/Prohróm). Inokedy sa jedno z prímen vzt’ahuje na floskulu: (Pásikár/Mliečko Prevarenvo). Niekedy je jedno prímeno vyvodené $\mathrm{z}$ toho druhého: Stoti/Stot'kár, Kuždro/Kuštra, Legánus/Leghánus, Lužam/Ludžan. Ked’ príslušníci jednej rozvetvenej rodiny 
zdedia prímeno, ktoré však nemá postačujúcu identifikačnú a dištinktívnu funkciu, potrebné je k nemu pridat' ešte jedno prímeno (Fugi Brankár, Fugi Richtár).

5. Hoci sú jednočlenné modely najčastejšie, zaznamenali sme i dvojčlenné opisné modely, ktoré sa vytvorili zložením dvoch slov (Bez oka, Bez vlasov, Ja Tarzam, Dolník makový, Koliba dotrhaná, Dobar dám, Jano malý, Jano velký, Pod orechom, $\mathrm{Na}$ kandrme). Následne sa aj ako zložené onymizovali (Bezoka, Kolibadotrhaná, Jatarzam, Podorechom, Nakandrme...)

6. Sú prípady, ked' muži majú za prímená ženské mená, zamestnania, ba i zvieratá ženského rodu (Babica, Čiernamara, Katica, Sova, Zuza). Inokedy sú vo funkcii prímen názvy podnikov alebo ich skratky (Alcmetál, Halogén, Klas, AS Auto Servis, RTS - Radio Televizija Srbije).

7. Niektoré prímená sa vzt'ahujú na niekol'ko osôb (v zátvorke uvádzame ich počet) istého alebo rozličného priezviska: Bačkoráš (2), Bádžo (3), Belzịkár (2), Bŕko (4), Bubnáš (2), Dugi (2), Ďemro (2), Holịar (3), Hrobár (3), Jayco (2), Kaydrmáš (2), Kít’o (3), Kochňịar (2), Kondáš (3), Kováč (3), Mitre (2), Ňmí (2), Pafo (2), Pišta (2), Profesor (2), Rus (2), Ribár (2), Sájo (2), Sváko (2), Š́ndor (2), Štraygár (3), Tamburáš (3), Tréner (2), Ťíro (2), Zvonár (2), Žíko (2).

8. V niektorých prímenách je zachované svedectvo o zamestnaniach, ktoré zanikajú: Starejší, Bačkoráš, Kondáš, Štrangár, Skeliar, Furmičkár...

\section{ZÁVERY}

Hoci $\mathrm{v}$ mikrosocietách asi polovica prímen býva motivovaná úradným krstným menom a priezviskom, $\mathrm{v}$ našom výskume sme zaznamenali širokú škálu motivantov.

Prímená najčastejšie majú pozitívny postoj $\mathrm{k}$ osobe, no je aj určitý počet takých, ktoré vznikli podl'a animozity (nepriatel'ského postoja a negatívnej emocionality).

V niektorých rodinách sú prímená dedičné, čo znamená, že príslušníci niekol'kých generácií tej rodiny majú tú istú prezývku. V iných prípadoch prímená sú individuálne, patriace výlučne jednej osobe a také prímeno väčšinou žije a zaniká spolu s tou osobou.

Sú priezviská, ktoré nemajú prímená. Dôvod je jednoduchý: nositel'mi toho priezviska boli málopočetné rodiny, takže postačujúcu identifikačno-diferenciačnú funkciu konalo $\mathrm{v}$ tých prípadoch krstné meno a priezvisko. V súčasnosti sme však zaznamenali jav, kde aj priezvisko, ktoré sa vyskytlo pri jednej rodine v Kysáči, má svoje prímeno. Vysvetl'ujeme to psycho-sociálnymi príčínami a potrebou individualizácie. 
Ženské prímená tvoria osobitnú kategóriu $\mathrm{v}$ našej práci. V porovnaní $\mathrm{s}$ mužskými prímenami najčastejšie sú diferencované gramatickou koncovkou. Spomíname ich iba okrajovo, takže sme ich bližšie neanalyzovali a nezaradili sme ich ani do úhrnného zoznamu.

Niektorí o svojich neúradných pomenovaniach ani nevedeli, ked’že sa používajú na identifikáciu tej osoby $\mathrm{v}$ jej neprítomnosti. Akceptácia prímena jej nositel'om je nepodstatná, v komunikácii funguje iba vtedy, ak ju prijme dedinský kolektív a tak nadobudne status l'udovosti.

Pre každú vojvodinskú lokalitu, v ktorej žijú Slováci, sú príznačné iné priezviská, no predpokladáme, že prímená týkajúce sa niektorých spomínaných kategórií (zvlášt' zamestnania) sa vyskytujú v rovnakej podobe v každej slovenskej vojvodinskej osade - čo by mohlo byt' predmetom d’alšieho výskumu.

Daniela Marčoková

Ana Makišová

\section{THE EPITHETS IN SURNAMES IN KISAC AS CULTURAL AND TRADITIONAL HERITAGE}

\section{Summary}

The occurrence of epithets in surnames is an ongoing sociolinguistic process. Our aim was to record all existing epithets, preserved by current inhabitants of Kysáč (Kisac). The results of our research can be summarized as follows: 165 recorded surnames contain 742 epithets in total, some family branches have many epithets; although monomial models are most frequent, binomial descriptive models also exist; in some cases a person has two epithets; some epithets refer to several persons; the relationship between the epithets and the person they refer to is, most commonly, positive, whereas in certain cases, the epithets occur because of animosity.

The role of the epithet is not only to identify the person it refers to, but it is also an important psychological, sociolological and historical factor. Epithets are a nonmaterial cultural and traditional heritage in some way reflecting the history of our towns describing the life of the people of the time and the place.

The local community stabilizes its values, norms and knowledge handing them down from one generation to another. However, there is a continuous decline of population in our local community, because of the mortality of old people and moving-away of the young. Furthermore, it is supposed that in the future, global crisis of social communication will be created due to decreased direct communication. For these reasons, our aim was to capture and record the information about epithets, which are still preserved by the inhabitants of Kysáč (Kisac) and to keep them for future generations.

Keywords: onomastics, epithets, Kysáč (Kisac), Slovacs in Serbia, cultural and traditional heritage 
Daniela Marčokova

Ana Makišova

\section{NADIMCI U KISAČU KAO KULTURNO I TRADICIONALNO NASLEĐE}

\section{Sažetak}

Nastanak nadimaka je živ sociolinvistički proces. Naš cilj je bio da zabeležimo sve nadimke koji su ostali sačuvani u živom sećanju sadašnjih stanovnika Kisača.

Rezultate našeg istraživanja možemo da sažmemo na sledeći način: kod 165 prezimena zabeležili smo ukupno 742 nadimka; neke razgranate porodice imaju puno nadimaka; iako su jednočlani modeli najčešći, zabeležili smo i dvočlane opisne modele; ponekad jedna osoba ima dva nadimka; neki nadimci se odnose na nekoliko osoba; nadimci najčešće imaju pozitivan stav prema osobi ali postoji određen broj takvih, koji su nastali prema animozitetu.

Nadimak ne služi samo za identifikaciju osobe, već ga možemo smatrati i važnim psihološkim, sociolingvističkim i istorijskim faktorom. Nadimci su nematerijalno - kulturno i tradicionalno nasleđe, koje na određen način reflektuju istoriju naših sela i na taj način karakterišu način života ljudi određenog doba i lokaliteta.

Lokalna zajednica stabilizuje vrednosti, norme i saznanja na osnovu generacijske transmisije. Nažalost, u našoj sredini dugoročno beležimo kako smanjenje članova najstarije generacije (smrti), tako i mlađe generacije (migracije). Osim toga, pretpostavljamo da će se u budućnosti produbiti opšta kriza socijalne komunikacije zbog ograničenja direktnih kontakata i povećanja tehničke komunikacije i u takvim mikrogrupama, kakvi su seoski kolektivi. Iz ovih razloga hteli smo da zabeležimo informacije o nadimcima koji su prisutni u živom sećanju stanovnika Kisača i da ih ostavimo u nasleđe generacijama koje dolaze.

Ključne reči: onomastika, nadimci, Kisač, Slovaci u Srbiji, kulturno i tradicionalno nasleđe

\section{LITERATÚRA}

Bauko, J. (2008). Prezývky v sústave antroponým. In: Gálisová, A.-Chomová, A. (ed.) (2008). Varia XV. Zborník materiálov z XV. Kolokvia mladých jazykovedcov (Banská Bystrica - Tajov 7.-9. 12. 2005). Bratislava: SJS pri SAV - Katedra slovenského jazyka a literatúry FHV UMB v Banskej Bystrici. 49-54.

Dudok, D. (1998). Priezviská Slovákov v Juhoslávii. Nový Sad: Spolok vojvodinských slovakistov.

Kiliánová, G. (ed.) (2011). Tradičná l’udová kultúra Slovenska slovom a obrazom (elektronická encyklopédia). Bratislava: Centrum pre tradičnú l’udovú kultúru, SL'UK, Ústav etnológie SAV, 2011 Ústav etnológie SAV. Dostupné na: <http://www.ludovakultura.sk/index.php?id=5886> 17.2.2017.

Krátky slovník slovenského jazyka (1989). Bratislava: Veda, vydavatel'stvo Slovenskej akadémie vied. 
Krško, J. (2004). Vplyv pohanstva a krest’anstva na formu vlastných mien našich predkov. In: Kožiak, R.-Nemeš, J. (ed.) (2004). Zborník z konferencie Pohanstvo a krestanstvo usporiadanej 5.-6. II. 2003 v Banskej Bystrici. Bratislava: Chronos. 211-216.

Krško, J. (2013). Interdisciplinárne dimenzie slovenskej onomastiky. In: Žeňuch, P. (ed.) (2013). Slavica Slovaca (red.). Bratislava: Slavistický ústav Jána Stanislava SAV. 3-9.

Murin, I. (2015). Terénny výskum obsahov kolektívnej pamäte a hermeneutická analýza dát. In: Jakoubek, M. (ed.) (2015). Studia ethnologica pragensia. Praha: Univerzita Karlova v Praze, č.7. 140-151. Dostupné na: http://cejsh.icm.edu.pl/cejsh/element/bwmeta1.element.desklight-900ef5c02f6a-4ff2-8600-002d4a88a6ab/c/ivan_murin_140-151.pdf.

Párnický, M. (s.a.). Kysáčske nádymky (rukopis)

Slovník slovenského jazyka III. diel p-r (1963). Bratislava: Vydavatel'stvo slovenskej akadémie vied.

Švecová, S. (1974). Príbuzenská skupina a patronýmia na Slovensku. In: Kiliánová, G. (ed.) (1974). Slovenský národopis. Bratislava: Ústav etnológie SAV, roč. 19, č. 1. 3-9.

Týr, M. (2004). Meno a národná identita. In: Slovenčina v praxi. Štúdie z konfrontačnej a aplikovanej lingvistiky. Nový Sad: Futura publikacije. 3845.

Týrová, Z. (2005). Prezývky Slovákov v obci Pivnica (Juhoslávia). In: Šimková, M. (ed.) (2005). Varia XII. Zborník materiálov z XII. kolokvia mladých jazykovedcov (Modra - Piesok 4.-6. 12. 2002). Bratislava: Slovenská jazykovedná spoločnost' pri SAV. 175-179.

Valentová, I. (2012). Poznámky k rozdielom medzi prezývkou a funkčným členom živého mena - individuálnou charakteristikou. In: Ološtiak, M. (ed.) (2012). Jednotlivé a všeobecné v onomastike. Zborník referátov z 18. slovenská onomastická konferencie (Prešov 12. - 14. september 2011). Prešov: Filozofická fakulta Prešovskej univerzity v Prešove. 113-122. Dostupné na: http://www.pulib.sk/elpub2/FF/Olostiak3/index.html.

Valentová, I. (2010). Prímeno, živé meno, individuálna charakteristika či prezývka? In: Ondrejovič, S. (ed.) (2010). Slovenská reč. Bratislava: Slovac Academic Press, roč. 75, č. $4-5.278-286$. 